\title{
Morphological Characterization of the Leukocytes in Circulating Blood of the Turtle (Phrynops hilarii)
}

\author{
Caracterización Morfológica de Leucocitos Circulantes en la Sangre de la Tortuga (Phrynops hilarii) \\ "Dimitrius Leonardo Pitol; ** João Paulo Mardegan Issa; "Flávio Henrique Caetano \& ${ }^{* *}$ Laurelúcia Orive Lunardi
}

PITOL, D. L.; ISSA, J. P. M.; CAETANO, F. H. \& LUNARDI, L. O. Morphological characterization of the leukocytes in circulating blood of the turtle (Phrynops hilarri). Int. J. Morphol., 25(4):677-682, 2007.

SUMMARY: The Phrynops hilarii specie of turtle has its characterization not well defined in the literature, it was proposed in this study the leukocyte characterization of the blood, stained by Leishman and analyzed under light and transmission electron microscope. It was not observe any cellular type with similar characteristics to neutrophils in mammalian group. We believed, based on the data obtained in this study that the heterophils have a morphofuncional analogy with another neutrophils belonged to mammalian group. This conclusion is being supported in many recent studies found in the literature.

KEY WORDS: Turtle; Morphology; Leukocytes; Blood.

\section{INTRODUCTION}

In mammals, leukocytes are easily identified on the basis of their morphological differences and the enzymes and other proteins stored in their cytoplasmic granules (Bainton \& Farquhar, 1968, 1970; Bainton et al., 1971; Weller, 1991; Dvorak et al., 1991, 1994). Neutrophils are highly specialized phagocytic cells involved in ingestion, death, and degradation of invading microorganisms (MacCall et al., 1971; Roos et al., 1983; Bainton, 1988). Eosinophils are cells that actively participate in the defense against parasitic infections, in the regulation of hypersensitivity reactions, and in the destruction of cancer cells (Kay, 1985; Dvorak et al., 1991; Weller).

Studies have been conducted on lower vertebrates in order to understand biological roles of leukocytes in defense mechanisms, and to establish phylogenetic studies and new experimental models. Some investigators have demonstrated the existence of 2 forms of eosinophils in the blood of turtles, one of them a mature form and the other an immature form (Jordan \& Flippin, 1943; Charipper \& Davis, 1932), whereas others have stated that there are 2 distinct cell lineages, i.e. neutrophils and eosinophils (Ryerson, 1943; Taylor et al., 1963; Wood \& Ebanks, 1984). Because of the wide morphological variation of these cells in different animal species, it is impossible to characterize them solely on the basis of morphology.

Veterinary haematology has relied on classical Romanowsky staining (e.g. Leishman, Wright and Giemsa) to identify erythrocytes, thrombocytes and leukocytes, but cellular classification of these leukocytes is not always reliable using classical staining methods. Neutrophils are present in some animals, but this cell types have been reported in a few species (Barber \& Westermann, 1978; Tavares-Dias \& Moraes). Immature leukocytes also can be present in circulating blood (Meseguer et al., 1994; TavaresDias \& Moraes, 2004). Thus, cytochemical staining of piscine leukocytes may be particularly useful for identification of cellular lineage and may suggest cell function.

Apart from being useful for identifying cell types in blood and tissues, cytochemical staining is also critical for identifying immunological cell types associated with developmental and pathological processes (Burrows \& Fletcher, 1987; Meseguer et al.; Lorenzi, 1999; Ueda et al., 2001; Petrie-Hanson \& Peterman, 2005). Presence of glycogen (Veiga et al., 2000; Ueda et al.; Vale et al., 2002; Rough et al., 2005) and alkaline phosphatase (Meseguer et

* Biosciences Institute- Molecular and Cellular Biology (UNESP), Rio Claro, São Paulo, Brazil.

** Faculty of Dentistry of Ribeirão Preto, University of São Paulo, Ribeirão Preto, São Paulo, Brazil. 
al.; Burrows et al., 2001) in leukocytes may be associated with phagocytosis. This requires the consumption of energy from both endogenous and exogenous sources (Hayhoe \& Quaglino, 1994; Ueda et al.). Peroxidase is a lysosomal enzyme, which takes part in intracellular digestion and modulation of phagocytic activity of leukocytes (Hayhoe \& Quaglino; Veiga et al.; Ueda et al.; Vale et al.; Azevedo \& Lunardi, 2003). Esterases are enzymes also related to cellular defense, facilitating diapedesis, cell migration through tissue, toxic product and microorganism inactivation and tumour cell destruction (Hayhoe \& Quaglino; Casaletti-Rosa \& Lunardi, 1997; Azevedo \& Lunardi). The need to identify these features in leukocytes encouraged numerous studies on turtles (Zinkl et al., 1991; Burrows et al.; Ueda et al.; Tavares-Dias \& Moraes; Palic et al., 2005; Petrie-Hanson \& Peterman).

By the fact that the Prynops hilarii specie has its characterization not well defined in the literature, it was proposed in this study the leukocyte characterization of the blood, stained by Leishman and analyzed under light and transmission electron microscope.

\section{MATERIAL AND METHOD}

All the aspects of this research were approved by local ethics committee. It was used in this study six Prynops hilarii turtles, obtained at Guaíba river, Porto Alegre, Rio Grande do Sul, Brazil. The animals were lodged for one week at Central Animals House, University of São Paulo, Ribeirão Preto, São Paulo, Brazil. The blood of these animals was removed by needle aspiration performed on lateral vessels of the neck. The histological process and staining of this blood was performed by Leishmann stain. These histological images were obtained at a photomicroscope using the Leica IM 50 program connected to Leica DMLB2 microscope.

The collected blood was done using heparinized beckers, centrifuged by 15 minutes at $1000 \mathrm{rpm}$ at room temperature. The blood plasma was eliminated and the leukocyte suspension was processed by electron microscopy analysis. Samples of the leukocyte suspension were fixed by Karnowsky solution- glutaraldehyde at $2 \%$, paraphormaldehyde at $2 \%$ and cacodilat solution at $0.1 \mathrm{M}$ pH 7.4, with $0.05 \%$ of calcium chlorite, during 2 hours at room temperature. The blood samples were post-fixed in osmium tetroxide at $1 \%$ and cacodilat solution $0.1 \mathrm{M}$, during two hours at the same temperature, and later, observed by CM-100 - Philips transmission electron microscope.

\section{RESULTS}

It was found in the present study six types of leukocytes in the turtle blood, Phrynops hillary specie, basophiles, eosinophils, lymphocytes, monocytes, neutrophils and thrombocytes. Basophiles presented spherical conformation with segmented nucleus, spherical granules in cytoplasm (Fig. 1A). Eosinophils were defined as spherical shape and peripheral nucleus, with cytoplasm filled by oval granules (Fig. 1B). Small and spherical lymphocytes, with eccentric nucleus, were observed in almost all cytoplasm (Fig. 1C). Monocytes cells were found in circulating blood, characterized by oval and peripheral nucleus and abundant cytoplasm (Fig. 1D). Neutrophils were found after light microscopy analysis, showing a spherical nucleus and heterophilic aspect, this cellular type was found in electron microscopy analysis, presenting segmented and heterophilic nucleus, and cytoplasm with elongated granules (Fig. 1E). Thrombocytes showed elliptic conformation, with a little cytoplasm and nucleus with elliptic shape too (Fig. 1F).

\section{DISCUSSION}

By the fact that the Prynops hilarii specie has its characterization not well defined in the literature, it was proposed in this study the leukocyte characterization of the blood, stained by Leishman and analyzed under light and transmission electron microscope.

Studies related to leukocytes characterization in turtles do not present a consensus in relation to the description of these leukocytes. Research studies related to ground turtles belonged to the species Terrapene carolina and Gopherus polyphenus, identified in blood samples the following cellular types, basophiles, eosinophils, lymphocytes, monocytes, neutrophils and thrombocytes (Ryerson, 1943). However, in 1962, Head \& Rogers working with four species of turtles did not related in their conclusion, the presence of basophiles in blood samples. In a similar study, performed in blood tissue of the turtle Chelonia mydas, it was not observed the presence of monocytes and it was considered the heterophils cells as neutrophils (Wood \& Ebanks, 1984). In 2004, Munoz \& Fuente, studying lymphoid tissues belonged to Mauremys caspica specie of turtle, found heterophils cells after the resultant histological analysis. Studies involving another species aiming to study the leukocytes under light microscopy analysis, showed in the turtles species Padocnemis expansa and Emys orbicularis, the presence 


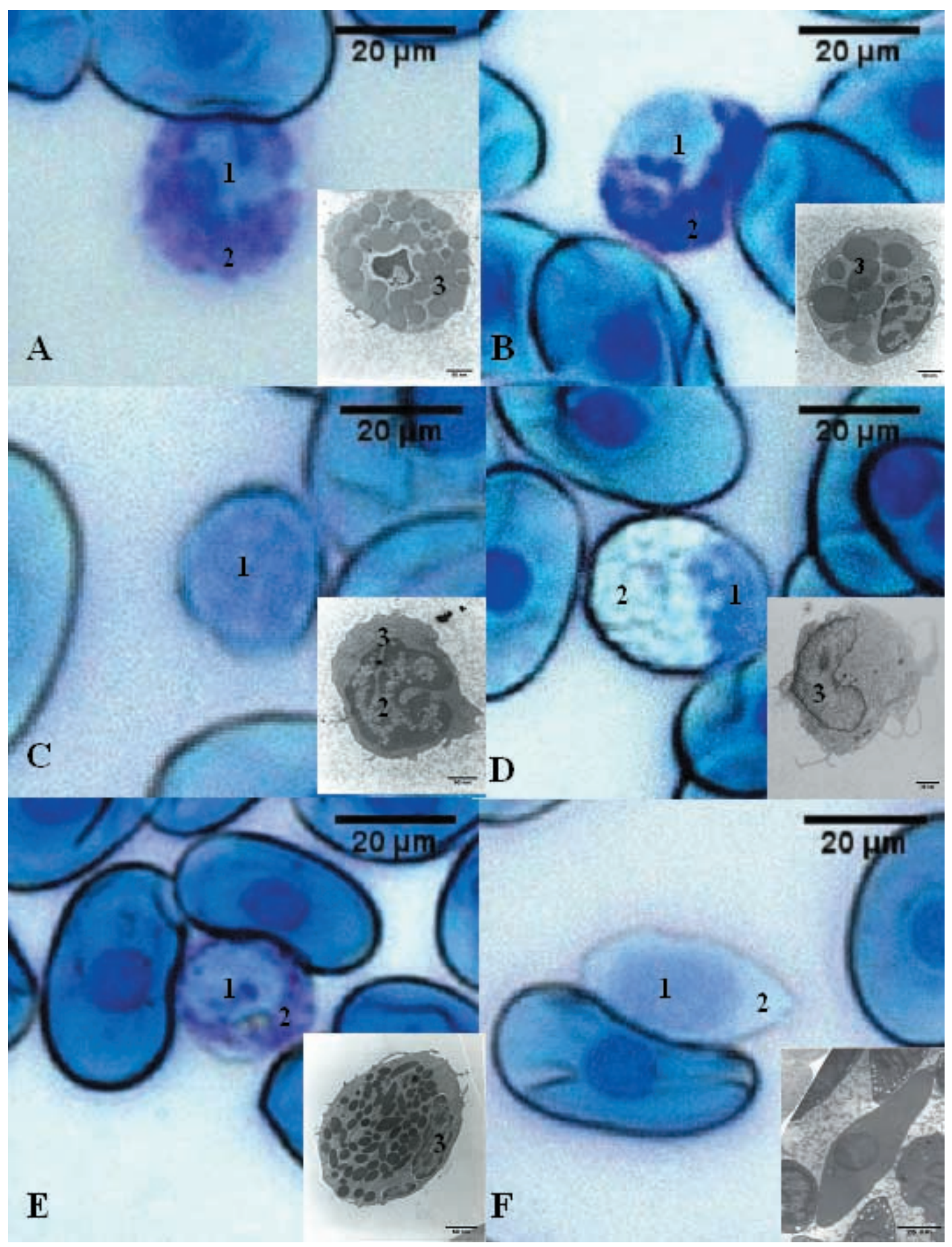

Fig. 1. A. Basophiles showing spherical shape with segmented nucleus (1), cytoplasm filled by many metachromatic granules (2) (400x of original magnification), granules with spherical shape under electron microscopy analysis (3) (2800x of original magnification). B. Eosinophils showing spherical shape and peripheral nucleus (1), cytoplasm filled by large granulus (2) (400x of original magnification). Granules with oval shape (3) (2500x of original magnification). C. Small lymphocytes with spherical shape and eccentric nucleus (1) filling almost all the cytoplasm (2) (400x of original magnification). However, when it is observed under electron microscope, the nucleus presented reniform aspect (3) (2500x of original magnification). D. Monocyte showing spherical shape with peripheral and reniform nucleus (1) and abundant cytoplasm (2) (400x of original magnification). Nucleolus under electron microscope (3) (2500x of original magnification). E. Heterophils (Neutrophils) showing spherical shape, central nucleus (1) and cytoplasm with elongated granules (2) observed under light microscope (400x of original magnification). However, when observed under electron microscope, it was found a peripheral and segmented nucleus (3) (2500x of original magnification). F. Thrombocytes showing an elliptic shape and nucleus with elliptic conformation too (1), and little quantity of cytoplasm (2) (400x of original magnification). 
of basophiles, eosinophils, lymphocytes, monocytes, and heterophils (Oliveira et al., 2000; Metin et al., 2006). Studies involving ultrastructural citochemistry analysis performed in Chrysemys dorbignih specie of turtle, confirmed the existence of eosinophils and heterophils in blood samples and different morphological characteristics of these cellular types according to some variations (Azevedo \& Lunardi).

The leukocyte identification is based on staining parameters and the morphology showed under light microscopy analysis, but it has some limits when this analysis is performed using leukocytes non granulocytic. Lymphocytes cells are in most cases classified as small, middle and large, and many authors relate the difficulty to analyze the differentiation of large lymphocytes in relation to monocytes or thrombocytes cells (Montali, 1988). Work, in 1998, analyzed the blood of Chelonia mydas specie, using sudan black B, periodic acid-schiff and toluidine blue, and cytochemistry reaction for acid phosphatase analysis and later identification of six types of leukocytes under electron microscope apparatus.

The results of the blood sample analysis stained by Leishmann, permitted to observe all leukocytes, being clear that the differences between monocytes and thrombocytes cells. These results associated to the transmission electron microscopy analysis, permitted to observe the characteristic shape of the basophiles, eosinophils, and heterophils granules in more detail, and to affirm that the leukocyte morphology in Phrynops hilarii specie is very similar to the another species and according to morphological descriptions found in the literature (Ryerson; Oliveira et al.; Azevedo \& Lunardi; Work et al.; Deen, 2006.). The Leishmann stain is used in most cases that the objective is to observe the hematological characteristics of the tissues in mammalian groups. Hughes et al., 2003 evidenced very well each cellular type in this group, thus we can affirm that this type of staining is an excellent method for diagnosis in chelonian blood samples.

It was not observe any cellular type with similar characteristics to neutrophils in mammalian group. We believed, based on the data obtained in this study that the heterophils have a morphofuncional analogy with another neutrophils belonged to mammalian group. This conclusion is being supported in many recent studies found in the literature.

PITOL, D. L.; ISSA, J. P. M.; CAETANO, F. H. \& LUNARDI, L. O. Caracterización morfológica de leucocitos circulantes en la sangre de la tortuga (Phrynops hilarri). Int. J. Morphol., 25(4):677-682, 2007.

RESUMEN: La especie de tortuga Phrynops hilarii no ha sido aún bien descrita en la literatura. Fue propuesto en este estudio la caracterización de leucocitos de sangre de este animal coloreados con el método de Leishman y analizados con microscopías de luz y electrónica. No fue observado ningún tipo celular con características similares a los neutrófilos de mamíferos. Los resultados indican que los heterófilos tienen analogía morfofuncional con otros neutrófilos presentes en el grupo de los mamíferos. Esta conclusión es sustentada por varios estudios recientes encontrados en la literatura.

PALABRAS CLAVE: Tortuga; Morfología; Leucocitos; Sangre.

\section{REFERENCES}

Azevedo,A. \& Lunardi, L. O. Cytochemical characterization of eosinophilic leukocytes circulating in the blood of the turtle (Chrysemys dorbignih). Acta Histochem., 105:99$105,2003$.

Bainton, D. F. \& Farquhar, M. G. Differences in enzyme content of azurophil and specific granules of polymorphonuclear leukocytes. Cytochemistry and electron microscopy of bone marrow cells. J. Cell. Biol., 39:299-317, 1968.

Bainton, D. F. \& Farquhar, M. G. Segregation and packaging of granule enzymes in eosinophilia. J. Cell. Biol., 45: 54-73, 1970 .
Bainton, D. F.; Ullyot, J. L. \& Farquhar, M.G. The development of neutrophilic polymorphonuclear leukocytes in human bone marrow: origin and content of azurophil and specific granules. J. Exp. Med., 134:907-34, 1971.

Bainton, D. F. Phagocytic cells: developmental biology of neutrophils and eosinophils. In Gallin, J. I.; Goldsteins, I. M. \& Snyderman, R. (Eds) Inflammation: basic principles and clinical correlates. Raven Press, New York NY, USA, pp 265-80, 1988.

Barber, D. L. \& Westermann, J. E. M. Occurrence of the periodic acid-Schiff positive granular leukocyte (PASGL) in some fishes and its significance. J. Fish. Biol., 12:35-43, 1978 . 
Burrows, A. S. \& Fletcher, T. C. Blood leukocytes of the turbot, Scophthalmus maximus (L.). Aquaculture., 67: 214-5, 1987.

Burrows, A. S.; Fletcher, T. C. \& Manning, M. J. Haematology of turbot, Psetta maxima (L.): ultrastructural cytochemical and morphological properties of peripheral blood leucocytes. J. Appl. Ichthyol., 17:77-84, 2001.

Casaletti-Rosa, L. \& Lunardi, L. O. Comparative study of the localization of nonspecific esterase activity (Naphthyl butyrate) in leucocytes from reptiles, birds and fish. Braz. J. Morphol.Sci., 14: 72, 1997.

Charipper, H. A. \& Davis, D. A. Study of the blood cells of Pseudemys elegans, with special reference to the polimorphonuclear leucocytes. Quart.Jou. Exp. Physiol., 21:372-82, 1932 .

Deen, S. L.; Dierenfeld, E.S.; Sounguet, G. P.; Alleman, A. R.; Cray, C.; Poppenga, R. H.; Norton, T. M. \& Karesh, W. B. Blood values in free-ranging nesting leatherback sea turtles dermochelys coriacea) on the coast of the republic of gabon. J.Zoo. Wild. Med., 37:464-71, 2006.

Dvorak, A. M.; Ackerman, S. J. \& Weller, P. F. Subcellular morphology and biochemistry of eosinophils. In: Harris JR (Ed) Megakaryocytes, platelets, macrophages and eosinophils. Blood cell biochemistry. Plenum, London, UK, pp 237-344, 1991.

Dvorak, A. M.; Estrella, P. \& Ishizaka, T. Vesicular transport of peroxidase in human eosinophilic myelocytes. Clin. Exp. Allergy., 24:10-8, 1994.

Hayhoe, F. G. J. \& Quaglino, D. Haematological Cytochemistry. London, Churchill Livingstone, 1994.

Head, J. M. \& Rogers, T. E. Turtle blood cell morphology. Proc. Iowa. Acad. Sci., 69:587-90, 1962.

Hughes, K. J.; Malikides, N.; Hodgson, D. R. \& Hodgson, J. L. Comparison of tracheal aspirates and bronchoalveolar lavage in race-horses: 1 . Evaluation of cytological stains and the percentage of mast cells and eosinophils. Aust. Vet. J.; 81:681-4, 2003.

Jordan, H. E. \& Flippin, J. Haematopoieses in chelonia. Folia. Haemat., 15:1-24, 1943.

Kay, A. B. Eosinophils as effector cells in immunity and hypersensitivity disorders. Clin. Exp.Immunol., 62:1-12, 1985.
Lorenzi, T. F. Manual de hematologia propedêutica e clínica. São Paulo, MDSI, 1999.

MacCall, C. E.; Caves, J.; Cooper, R.; De Chatelet, L. Functional characteristics of human toxic neutrophils. J. Infect. Dis., 124:68-75, 1971 .

Meseguer, J.; López-Ruiz, A. \& Angeles-Esteban, M. Cytochemical characterization of leucocytes from the seawater teleost, gilthead seabream (Sparus aurata L.). Histochemistry., 102:37-44, 1994.

Metin, K.; Turkozan, O.; Kargin, F.; Koca, Y.; Taskavak, E. \& Koca, S. Blood cell morphology and plasma biochemistry of the captive European pond turtle Emys orbicularis. Acta. Vet. Brno., 75:49-56, 2006.

Montali, R. J. Comparative pathology of inflammation in the higher vertebrates (reptiles, birds and mammals). J. Comp. Pathol., 99:1-27, 1988.

Munoz, F. J. \& Fuente, M. D. L. Seasonal Changes in Lymphoid Distribution of the Turtle Mauremys caspica. Copeia., 1:178-83, 2004.

Oliveira, R. C.; Beletti, M. E.; Silva, Silva. \& Santos, A. L. Q. Caracterização Morfológica dos leucócitos da tartaruga da amazônia (Padocnemis expansa) em microscopia de luz. Biosc. J., 16:1-8, 2000.

Palic, D.; Andreasen, C. B.; Frank, D. E. \& Menzel, B.W.; Roth, J.A. Gradient separation and cytochemcial characterisation of neutrophils from kidney of fathead minnow (Pimephales promelas Rafinesque, 1820). Fish \& Shellfish Immunol., 18:263-7, 2005.

Petrie-Hanson, L. \& Peterman, A.E. American paddlefish leukocytes demonstrate mammalian-like cytochemical staining characteristics in lymphoid tissues. J. Fish. Biol.; 66:1101-15, 2005.

Roos, D.; Voetman, A. A. \& Meerhof, L. J. Functional activity of enucleated human polymorphonuclear leukocytes. J. Cell. Biol., 97:368-77, 1983.

Rough, K. M.; Nowak, B.F. \& Reuters, R. E. Haematology and leukocyte morphology of wild caught Thunnus maccoyii. J. Fish. Biol., 66:1649-659, 2005.

Ryerson, D. L. Separation of the two acidophilic granulocytes of turtle blood with suggested phylogenetic relationships. Anat. Rec., 85:25-46, 1943. 
Tavares-Dias, M. \& Moraes, F. R. Hematology in Teleost Fish. Sao Paulo, Ribeirao Preto (in Portuguese), 2004.

Taylor, K.W.; Kaplan, H. M. \& Hirano, T. Electron microscope study of turtle blood cells. Cytologia, 28:248$56,1963$.

Ueda, I. K.; Egami, M. I.; Sasso, W. S. \& Matushima, E.R. Cytochemical aspects of the peripheral blood cells of Oreochromis (Tilapia) niloticus (Linnaeus, 1758), (Cichlidae, Teleostei)-Part II. Braz. J. Vet. Animal. Sci., 38: 273-77, 2001.

Vale, A.; Afonso, A. \& Silva, M.T. The professional phagocytes of sea bass (Dicentrarchus labrax L.): cytochemical characterisation of neutrophils and macrophages in the normal and inflamed peritoneal cavity. Fish \& Shellfish Immunol., 13:183-98, 2002.

Veiga, M. L.; Egami, M. I.; Ranzani-Paiva, M. J. T. \& Rodrigues, E. L. Aspectos morfológicos y citoquímicos de las células sanguíneas de Salminus maxilosus Valenciennes, 1840 (Characiformes, Characidae). Rev. Chil. Anat., 18:245-50, 2000.

Weller, P. F. The immunobiology of eosinophils. New. Eng. J.Med., 34:1110-8, 1991.

Wood, F. E. \& Ebanks, G. K. Blood cytology and hematology of the green sea turtle, chelonia mydas. Herpetologia, 40: 331-36, 1984.

Work, T. M.; Raskin, R. E.; Balazs, G. H. \& Whittaker, S.D. Morphological and cytochemical characteristics of blood cells from Hawaiian green turtles. Am. J. Vet. Res., 59:1252-7, 1998.

Zinkl, J.G.; Cox, W. T. \& Kono, C.S. Morphology and cytochemistry of leucocytes and thrombocytes of six species of fish. Comp. Haematol. Internat., 1:187-95, 1991.
Correspondence to:

Dr. Dimitrius Leonardo Pitol

Faculdade de Odontologia de Ribeirão Preto - USP

Departamento de Morfologia, Estomatologia e Fisiologia CEP: $14040-904$

Av. Café S/N,

Ribeirão Preto, SP

BRASIL

Phone: $+55-16-36024095$

Fax: +55-16-36330999

Email: dimipitol@yahoo.com.br

Received: 20-06-2007

Accepted: 24-08-2007 